
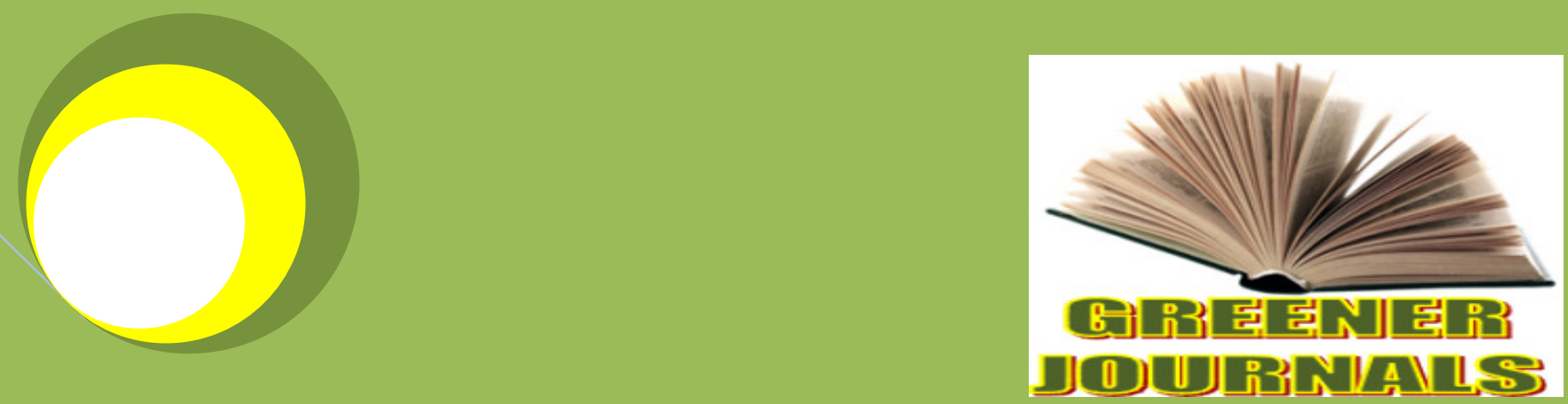

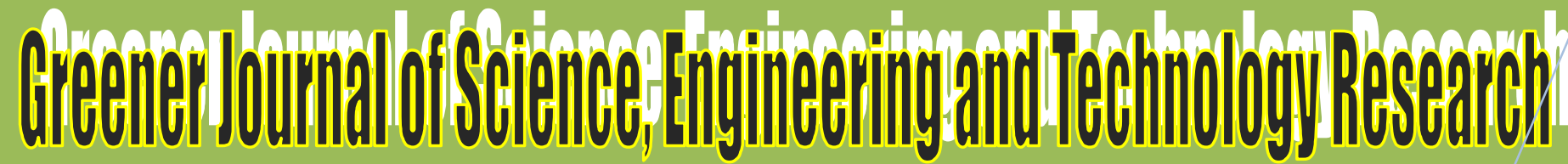
ISSN: 2276-7835 Impact Factor 2012 (UJRI): 0.7563 ICV 2012: 5.62

Air Pollution: A Case Study on Suspended Air Particulate Matter at Aman Perdana, Klang, Selangor. Malaysia

By

Ali M.F.

Abd-Rahman H.S. 


\title{
Air Pollution: A Case Study on Suspended Air Particulate Matter at Aman Perdana, Klang, Selangor. Malaysia
}

\author{
*Ali M.F. and Abd-Rahman H.S. \\ Faculty of Civil Engineering, Universiti Teknologi MARA, 40450 Shah Alam, Selangor, Malaysia. \\ *Corresponding Author’s Email: mohdfozi@salam.uitm.edu.my
}

\begin{abstract}
This paper was aimed to determine the level of particulate matter that satisfies the requirements of Malaysia Ambient Air Quality Guidelines (MAAQG) and World Health Organization (WHO), which includes the tracing of the concentration of heavy metal in dust samples. The study of ambient air quality was conducted at Aman Perdana, Klang, Selangor, Malaysia where the sampling of each size of the $\mathbf{P M}_{10}, \mathbf{P M}_{2.5}$ and $\mathbf{P M}_{1}$ was conducted within three days in order to determine the concentration levels. However, the sampling of $\mathbf{P M}_{10}$ was conducted over a period of five months to determine the concentration pattern. The dust sampling was conducted to trace and determine the concentration of heavy metal in the dust. Element of heavy metal was chosen based on the first batch sample screening namely Aluminium, Arsenic, Calcium, Cadmium, Chromium, Iron, Potassium, Magnesium, Nickel, Lead and Zinc. Methodically, the dust samplings, filter digestion and tracing heavy metal were determined by using the Real Time Aerosol Monitoring System (E-Sampler), Milestone Microwave Laboratory System (ETHOS Touch Control) and Inductively Coupled Plasma Optical Emission Spectroscopy (Perkin Elmer Optima 7300 DV) respectively. The values of $\mathbf{P M}_{10}, \mathbf{P M}_{2.5}$ and $\mathbf{P M}_{1}$ are within the ranges of $55 \mu \mathrm{g} / \mathrm{m}^{3}$ and $25 \mu \mathrm{g} / \mathrm{m}^{3}, 42 \mu \mathrm{g} / \mathrm{m}^{3}$ and $20 \mu \mathrm{g} / \mathrm{m}^{3}$, and $42 \mu \mathrm{g} / \mathrm{m}^{3}$ and $20 \mu \mathrm{g} / \mathrm{m}^{3}$ inclusive, respectively. The analysis, which reflects the important step forward in the evaluation of environmental quality, reveals that on average, concentration of the three types of aerodynamic sizes is below the permissible limit of MAAQG, however, several data exceeded the maximum allowable limit of the World Health Organization (WHO, 2005), for examples, Calcium was recorded with higher concentration of $86 \mathrm{ppm}$ and the lowest is Zinc $0.5 \mathrm{ppm}$.
\end{abstract}

Keyword: Particulate Matter (PM), Heavy metal Element, Real Time Monitoring System, ICP-OES.

\section{INTRODUCTION}

Ambient air quality is defined as the surrounding air quality or open space situation, that the condition of the air in the outdoor environment, directly affects the health of humans and ecosystems. The rising air pollution environmentally degraded the ambient quality of the air thus, various standards and regulations were established in the lights of addressing the issue. According to Vellero (2008), ambient air pollution is divided into anthropogenic pollution or nonanthropogenic, stationary or mobile sources and indoor or outdoor pollution. Talib et.al (2002), postulated that the main cause of ambient air pollution spreads from industrial effluents, open burnings, agricultural activities and emissions from vehicles. On the other hand, the indoor air quality refers to the enclosed environment spread from smoking, vapour of building materials, cooking, heating and hobby activities (Colome, et.al, 1992). Conversely, outdoor air quality refers to the outside condition that is widespread based on meteorological condition, location and surrounding development (Peavy et.al., 1985).

Malaysia is now moving towards a developed country, this effort required tradeoffs between the economic development and environmental quality. The rising economic development and human activities have resulted in poor air pollution and the occurrence of urban heat island. As a result, excessive poisonous gases and heat emitted more frequent as in daily basis. 


\section{METHODOLOGY}

\section{Site Description}

Klang is one of the oldest areas in Selangor, Malaysia that covers the surface area of $636 \mathrm{~km}^{2}(\mathrm{MPK}, 2011)$ with the population 832,600 reported by Department of Statistic Malaysia (DoS, 2011). Approximately, 70\% of its activities comes from the industrial sectors, regardless of the size of the industry has made Klang one of the developed districts in Selangor. Due to this situation, some residential area has reported poor air quality or, in other words, increasing air pollution due to those engaging industrial activities from various sectors. In order to verify and provide evidence for complaints from residents, the study on the level of suspended air particulate matter less than 10 microns will be conducted and also to determine the concentration level and type of the heavy metal consist in the dust. Furthermore, this study will investigate the level of particulate matter in Aman Perdana whether it conforms to the standards that have been set by both Malaysia Air Quality Index (MAQI) and World Health Organization (WHO).

\section{Sampling}

The concentration level of suspended particulate matter was measured at four different stations, which are marked as Station A, B, C, and D in Figure 1.1. The sampling locations were selected based on the nearest receiving area or receptor of particulate matter. Additionally, the equipment setting decided based on possible to access the area. The measurement on-site was aimed on Suspended Particulate Matter 10 $\mu \mathrm{m}\left(\mathrm{PM}_{10}\right), 2.5 \mu \mathrm{m}\left(\mathrm{PM}_{2.5}\right)$ and $1 \mu \mathrm{m}\left(\mathrm{PM}_{1}\right)$ and collected by using the Real Time Aerosol Monitoring System (E-Sampler 9800). The type of filter used was Mitex membrane filter with the chemical compound PTFE hydrophobic. Millipore sizes with five micrometers, $25 \mathrm{~mm}$ surface area and $170 \mathrm{~mm}$ wide. The PTFE hydrophobic membrane was installed into the E- sampler and left at the four stations continuously 24 hours (8am to $8 a m$ the next day).

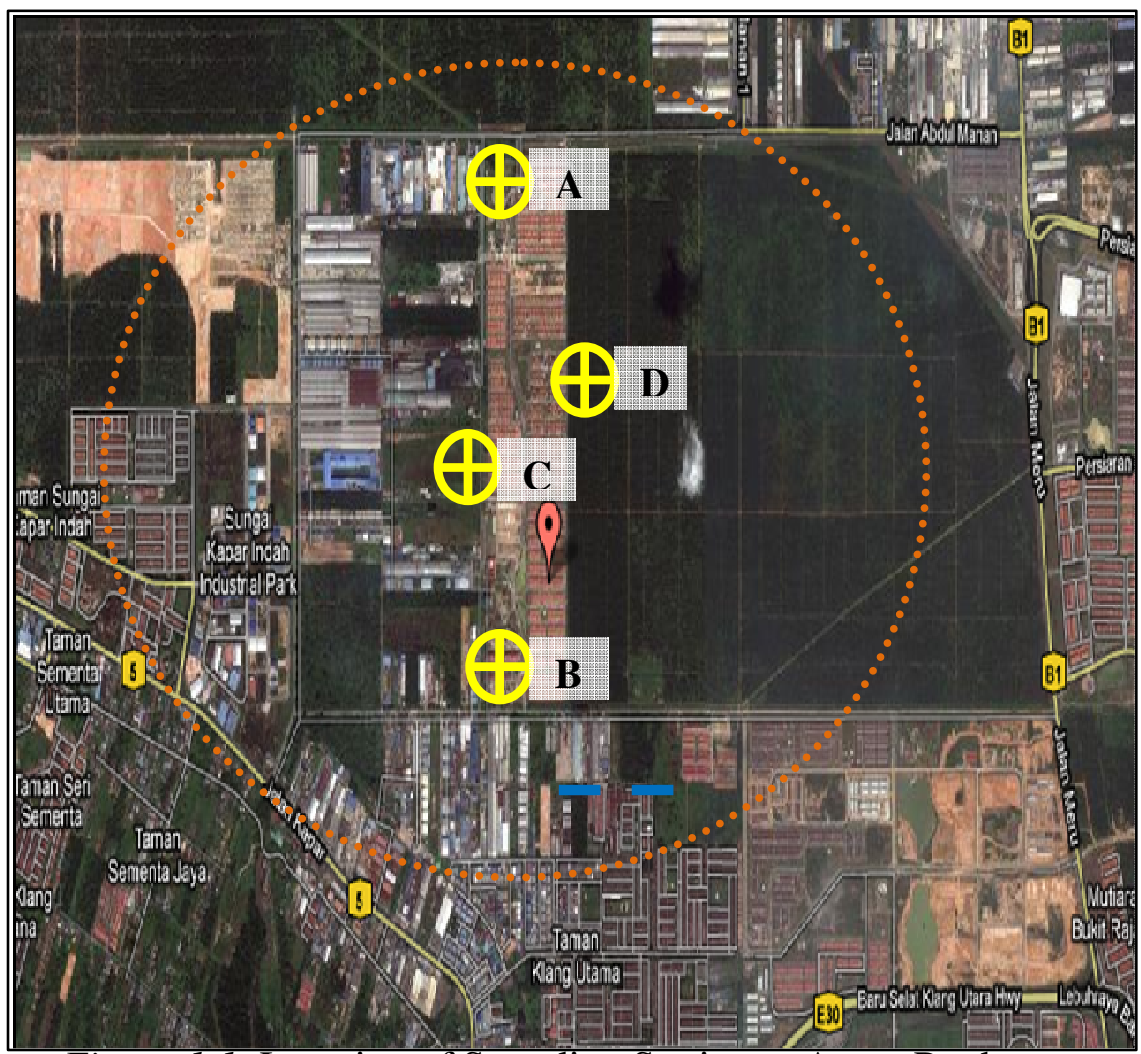

Figure 1.1: Location of Sampling Station at Aman Perdana 


\section{Samples Digestion}

The microwave digestion method was adopted in order to digest PTFE membrane filter and Kim wipes tissue. The first trials of digestion used the reagent with the $7 \mathrm{~mL} \mathrm{HNO}_{3}$ with $65 \%$ and $3 \mathrm{~mL} \mathrm{HCL}$ with $37 \%$ and start to digest using the microwave digester within 45 minute. Next, the second trial used $4 \mathrm{~mL}$ of (Nitrate) $\mathrm{HNO}_{3}$ and $1 \mathrm{~mL}$ of Hydrogen Peroxide $\left(\mathrm{H}_{2} \mathrm{O}_{2}\right)$. The filter solutions dilute to $100 \mathrm{~mL}$ with the ultra-pure water in a volumetric flask and kept at $4^{\circ} \mathrm{C}$ in a polyethylene bottle until analysis was conducted.

\section{Data Analysis}

The concentration level of heavy metals for digestion sample and rainwater were analysed using Inductively Coupled Plasma-OES (Perkin Elmer Optima 7300 DV). For all metals analysed, four point calibration procedures were adopted. Calibration solutions for every heavy metal were prepared by serial dilution from a standard stock solution. In order to ensure that the result were not affected by any interference, concentration of calibration solutions prepared for 28 elements of heavy metal were $10.00 \mathrm{ppm}, 1.00 \mathrm{ppm}, 0.10 \mathrm{ppm}, 0.01 \mathrm{ppm}$, and $0.00 \mathrm{ppm}$. In the solution preparation, ultra pure water $(18 \mathrm{M} \Omega \mathrm{cm}$ resistivity) was used and these calibrations were done using freshly prepared standards.

\section{RESULTS AND DISCUSSION}

\section{Comparing Particulate Matter Concentration with Wind Speed, Relative Humidity and Temperature Factors}

The maximum concentration of $\mathrm{PM}_{10}$ is $55 \mu \mathrm{g} / \mathrm{m}^{3}$ with the $2.1 \mathrm{~km} / \mathrm{h}$, relative humidity $67 \%$ and temperature $31.6^{\circ} \mathrm{C}$. Meanwhile, the minimum concentration $\mathrm{PM}_{10}$ is $25 \mu \mathrm{g} / \mathrm{m}^{3}$ with the $2.42 \mathrm{~km} / \mathrm{h}$, relative humidity $65.78 \%$ and temperature $32^{\circ} \mathrm{C}$. Based on the value obtained, the maximum concentration of particulate matter shows that during low wind speed, relative humidity and temperature have not much differ. Figure 1.2A shows maximum wind speed reported $4.87 \mathrm{~km} / \mathrm{h}$ but concentration of the $\mathrm{PM}_{10}$ is $33 \mu \mathrm{g} / \mathrm{m}^{3}$. This suggested that there is no significant correlation between wind speed and concentration of particulate matter. In the precedent discussion, it was approved by Mulloli et.al. (2000) and Byrd et.al. (2010), that proposed there is no strong evidence on the relationship between particulate matter and wind speed. However, Meyer and Rupprecht (1996), as shown in Figure 1.2B and 1.2C claimed that temperature and relative humidity have good correlation in spreading the air pollution.

\section{Analysis of heavy Metal Using Inductively Coupled Plasma (ICP-OES)}

Refer to Figure 1.3, the maximum concentration particulate matter $\left(\mathrm{PM}_{2.5}\right)$ recorded is $42 \mu \mathrm{g} / \mathrm{m}^{3}$ with average of wind speed $2.4 \mathrm{~km} / \mathrm{h}$, relative humidity is $61.39 \%$ and the temperature is $30.6^{\circ} \mathrm{C}$. Conversely, the minimum concentration of $\mathrm{PM}_{2.5}$ is $20 \mu \mathrm{g} / \mathrm{m}^{3}$ with the $2.3 \mathrm{~km} / \mathrm{h}$ wind speed, $65.4 \%$ relative humidity and $30.2^{\circ} \mathrm{C}$. Additionally, comparisons on the concentration of $\mathrm{PM}_{1}$ between wind speeds, relative humidity and temperature were recorded as in Figure 1.4. The maximum values of $\mathrm{PM}_{1}$ concentrations were compared with the wind speed recorded are $36 \mu \mathrm{g} / \mathrm{m}^{3}, 3.5 \mathrm{~km} / \mathrm{h}$, $60.2 \%$ and $31.2^{\circ} \mathrm{C}$ respectively. Plus, there is no significant relationship between wind speed and the spreads of particulate matter.

Based on Figure 1.5, maximum concentration was obtained during day 1 to day 4 . On average, the maximum concentration $\mathrm{PM}_{10}$ at Station $\mathrm{A}, \mathrm{B}, \mathrm{C}$, D was recorded $26 \mu \mathrm{g} / \mathrm{m}^{3}, 39 \mu \mathrm{g} / \mathrm{m}^{3}, 20 \mu \mathrm{g} / \mathrm{m}^{3}$ and $29 \mu \mathrm{g} / \mathrm{m}^{3}$ respectively. The higher concentration level at each station recorded on the nonworking period between on Friday to Monday. This may possibly at certain period of effluent collection throughout industrial process need to be emitted before the processing continue on the next working period.

Based on the Table 1.1, on average, Calcium detected the maximum concentration with mean $86.265 \mathrm{ppm}$ and the minimum reading with mean 13.625ppm. Then followed by Iron with the maximum concentration 38.405ppm and minimum concentration is $11.449 \mathrm{ppm}$. Separately, the maximum concentration of Aluminium is $20.385 \mathrm{ppm}$ and minimum concentration detected 6.083ppm. Magnesium and Zinc detected with maximum concentration 8.787ppm and 7.130ppm respectively. Referring to the results obtained, on average, Lead, Arsenic and Zinc were recorded between the range of $0.020 \mathrm{ppm}$ to $0.250 \mathrm{ppm}, 0.009 \mathrm{ppm}$ and $0.550 \mathrm{ppm}$ to $7.000 \mathrm{ppm}$ respectively. However, Cadmium value is not detected. Based on the results obtained, it was proven that Lead and Zinc exceeded the DOE permissible limit however, Arsenic still below the limit. According to the Agencies for Toxic Substances and Disease Registry (ATSDR, 2008), the list of hazardous substances started with Arsenic, followed Mercury and Cadmium. Based on the statement, OSHA sets that worker exposures of hazardous particulate matter do not exceed $10 \mu \mathrm{g} / \mathrm{m}^{3}$ the permissible exposure limit (PEL) over 8hour per day (ATSDR, 2009). Whereas, $\mathrm{NIOSH}$ recommended $2 \mu \mathrm{g} / \mathrm{m}^{3}$ is 
the limit of worker exposure. A study done by Lugo et.al (1969) has proven that the non-occupational exposure to arsenic can increase the exposure to the foetus. According to Yip and Dart (2001), the exact amount of Arsenic absorbed by inhalation has not been determined precisely but it will cause lung damage about $60 \%$ to $90 \%$. However, NIOSH requirement is Lead $100 \mu \mathrm{g} / \mathrm{m}^{3}$ and it is non-enforceable. According to EPA, the permissible limit exposure of lead should be a minimum of $0.15 \mu \mathrm{g} / \mathrm{m}^{3}$ with 3 -months average. ATSDR (2008) claimed that $1 \%$ exposure of level greater or equal $10 \mu \mathrm{g} / \mathrm{m}^{3}$ can present risks to developing foetuses.

Based on the Table 4.3, concentration of Zinc obtained was between $0.55 \mathrm{ppm}$ to $7 \mathrm{ppm}$. OSHA sets the average legal limit exposure of $0.05 \mathrm{ppm}$ Zinc in the workplace over the 8 hours weekdays and 40 hours of the working week. Inhaling large amounts of Zinc (as zinc dust or fumes from smelting or welding) can cause a specific short-term disease called metal fume fever (ATSDR, 2005).

The death occurred 13 days after the 90 -minutes exposure to an estimated concentration of $382 \mathrm{mg} \mathrm{Ni} / \mathrm{m}^{3}$ of principally metallic Nickel with the majority of particle sizes of $<1.4 \mu \mathrm{m}(\mathrm{ATSDR}, 2005)$ and Copper permissible limit measured in a range between 6.9 and 20 miligrams/meter (ATSDR, 2010).

\section{CONCLUSION}

Based on the field study conducted the concentrations of $\mathrm{PM}_{10}, \mathrm{PM}_{2.5}, \mathrm{PM}_{1}$ falls in the range of $55 \mu \mathrm{g} / \mathrm{m}^{3}$ to $25 \mu \mathrm{g} / \mathrm{m}^{3}$, $42 \mu \mathrm{g} / \mathrm{m}^{3}$ to $20 \mu \mathrm{g} / \mathrm{m}^{3}$ and $30 \mu \mathrm{g} / \mathrm{m}^{3}$ to $11 \mu \mathrm{g} / \mathrm{m}^{3}$ respectively. However, several results have exceeded the WHO (2005) permissible exposure limit. According to the WHO (2005), particulate matter with less $2.5 \mu \mathrm{m}$ cannot exceed the range of $3 \mu \mathrm{g} / \mathrm{m}^{3}$ to $5 \mu \mathrm{g} / \mathrm{m}^{3}$. This is crucial to avoid adverse impacts on human health. Nevertheless, in the study on heavy metal elements, no ambient air regulation can compare the results except in EQA (2011) that stated the seven hazardous elements that only regulated for the operation of industrial activities. Referring to the result obtained, on average Lead, Arsenic, Zinc, recorded between $0.02 \mathrm{ppm}$ to $0.25 \mathrm{ppm}, 0.009 \mathrm{ppm}$ and $0.55 \mathrm{ppm}$ to $7 \mathrm{ppm}$ respectively. According to the Agencies for Toxic Substances and Disease Registry (ATSDR, 2008), Arsenic is placed on top of the list of hazardous substances that can be severed to the human well-being. As a conclusion, OSHA, NIOSH, EPA and ATSDR have done several studies on the effect of heavy metal on human health and developed permissible limits in order to decrease the percentage mortality of the world

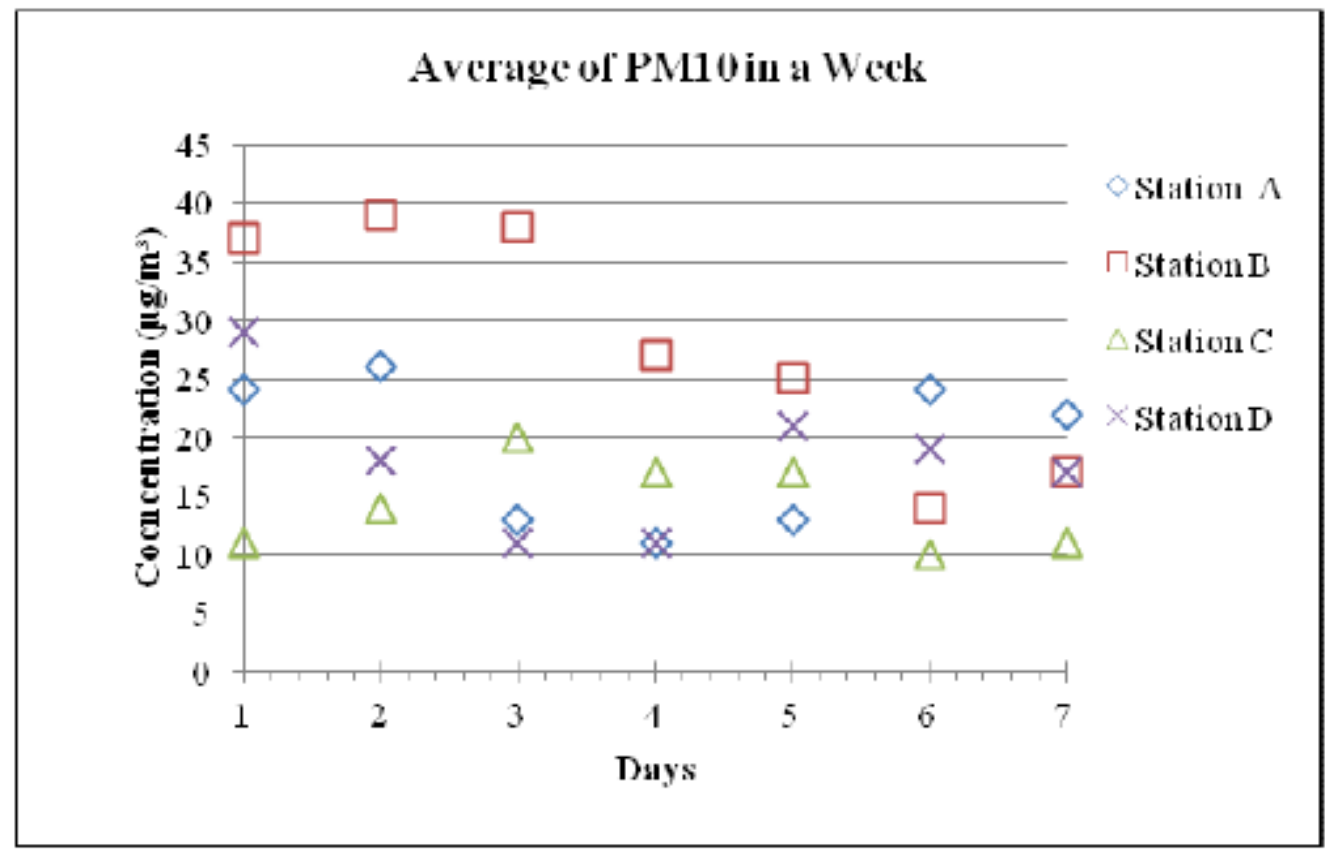

Figure 1.5: Average of $\mathrm{PM}_{10}$ in a Week at Aman Perdana. 


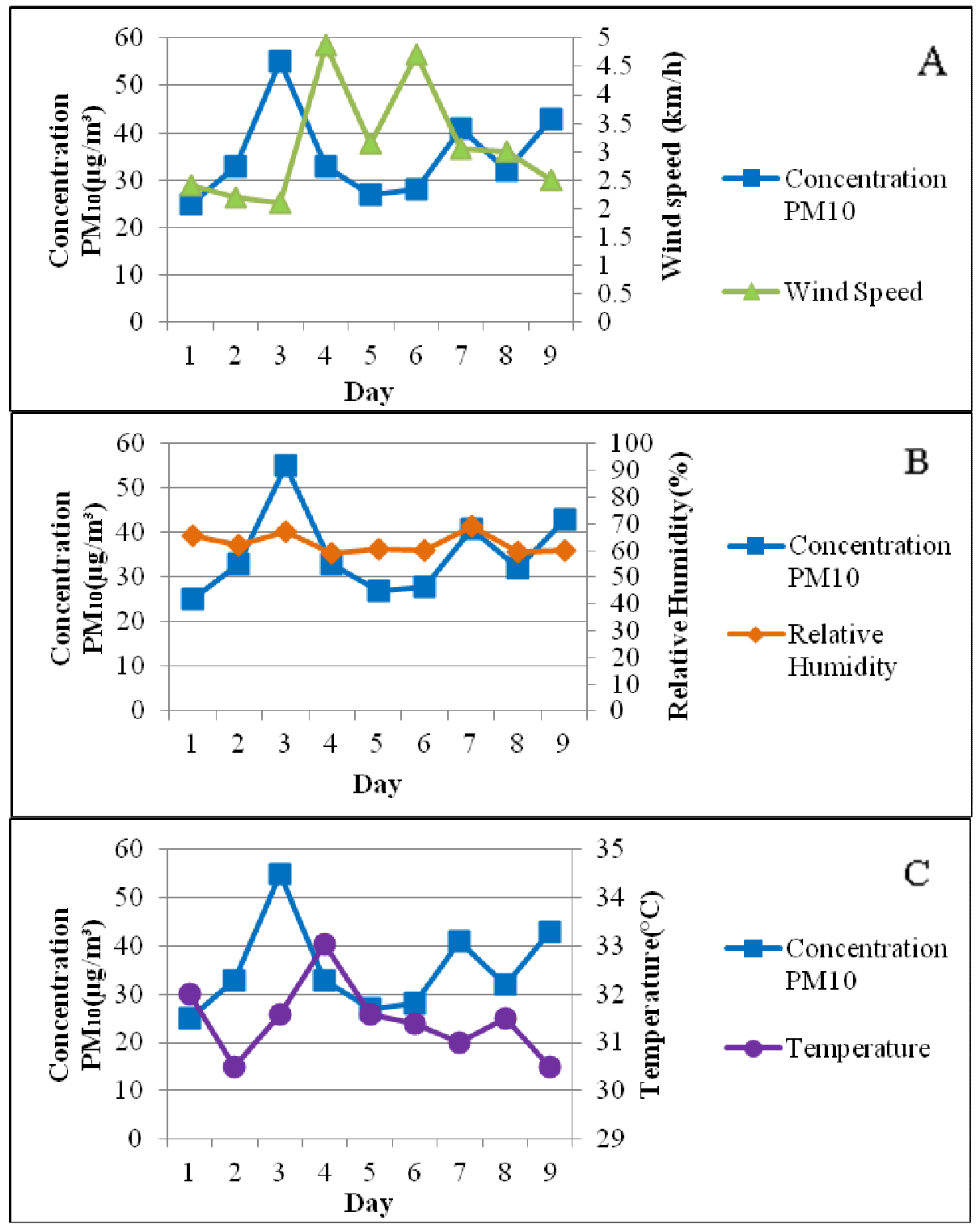

Figure 1.2: A) Graph of $\mathrm{PM}_{10}$ vs. Wind Speed; B) Graph of $\mathrm{PM}_{10}$ vs. Relative Humidity; C) Graph of $\mathrm{PM}_{10}$ vs. Temperature 


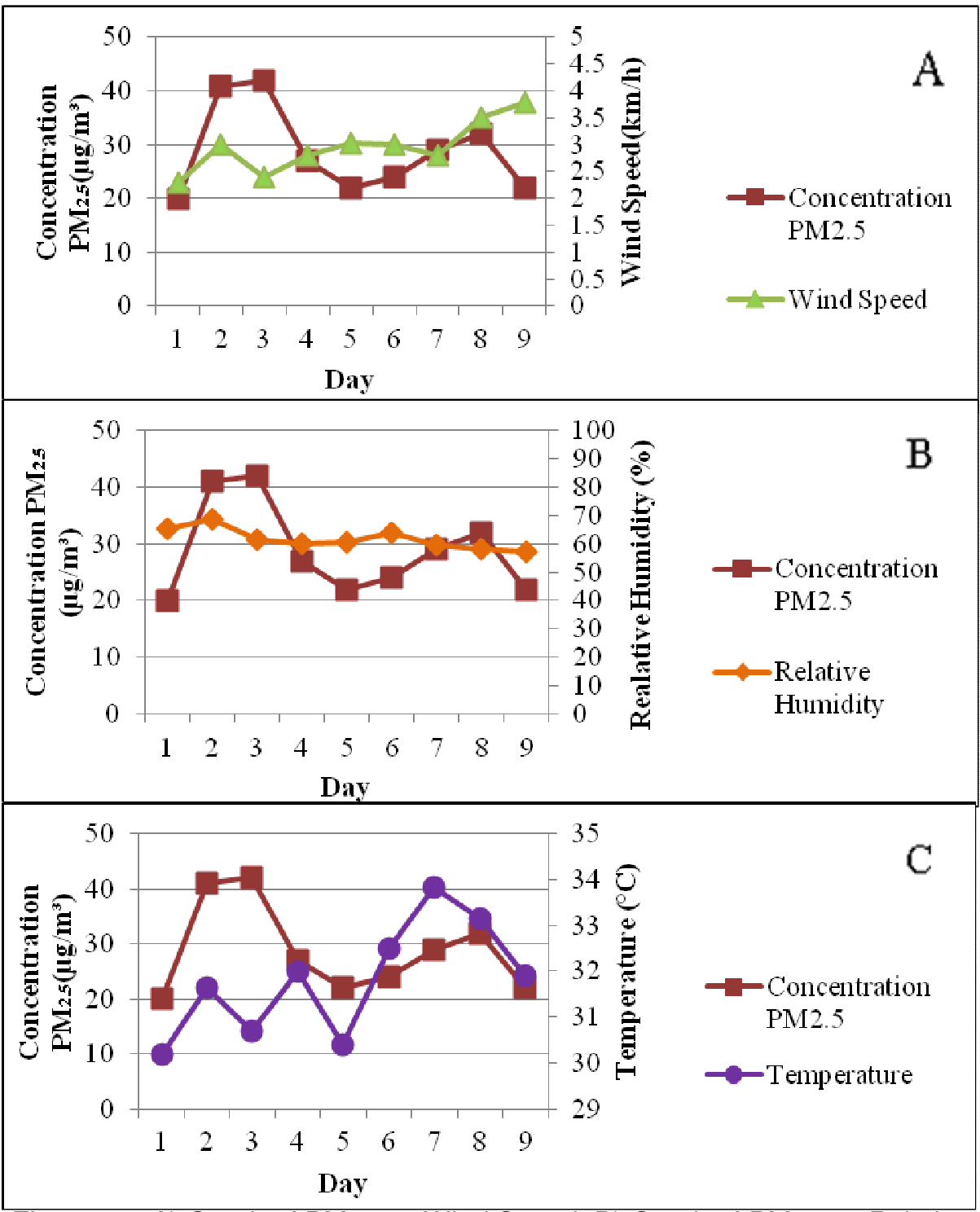

Figure 1.3: A) Graph of $\mathrm{PM}_{2.5}$ Vs. Wind Speed; B) Graph of $\mathrm{PM}_{2.5}$ Vs. Relative Humidity; C) Graph of $\mathrm{PM}_{2.5}$ vs. Temperature 


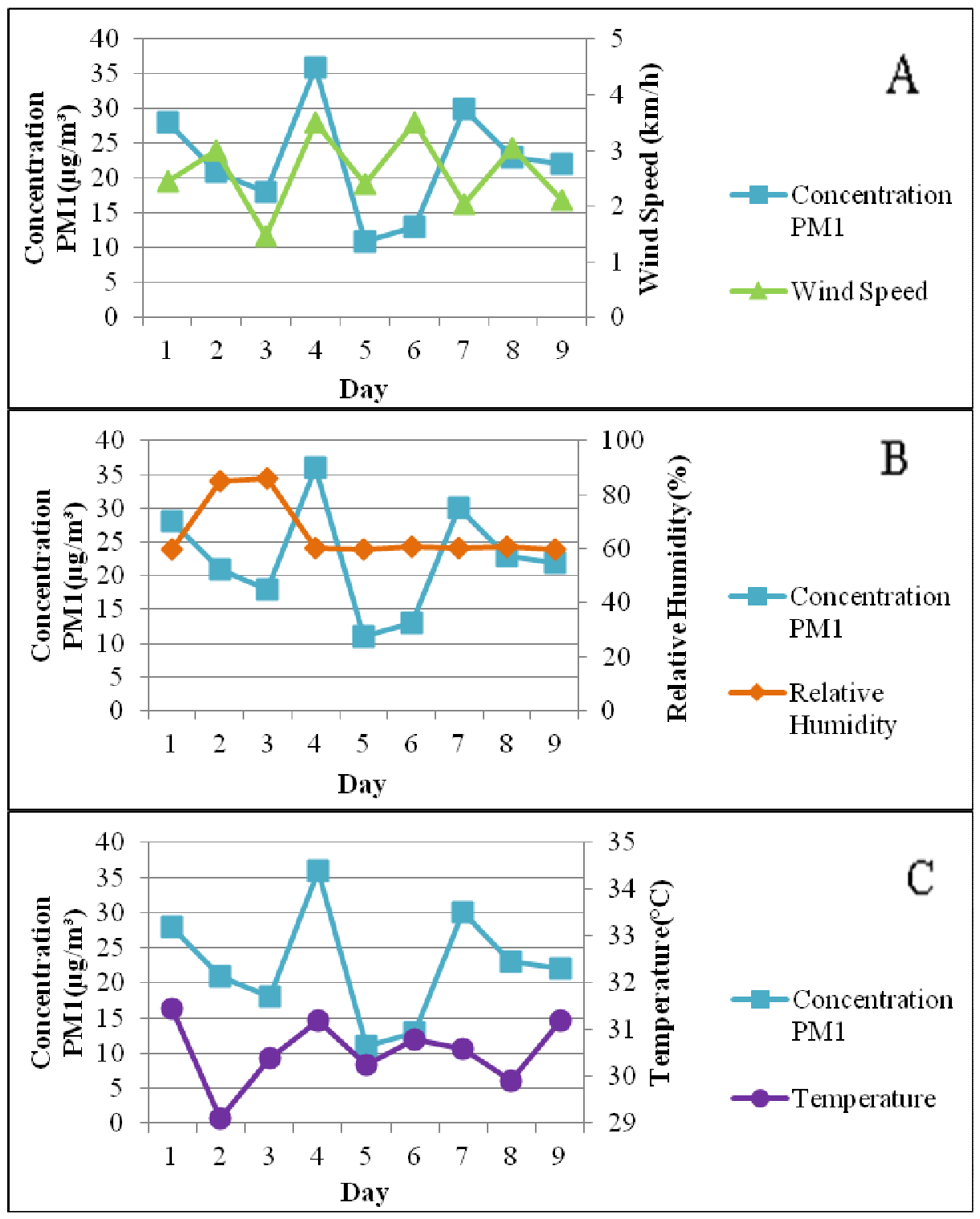

Figure 1.4: A) Graph of $\mathrm{PM}_{1}$ vs. Wind Speed; B) Graph of $\mathrm{PM}_{1}$ vs. Relative Humidity; C) Graph of $\mathrm{PM}_{1}$ vs. Temperature 
Table 1.1.: Summaries of Heavy Metal Using Dust Sample of Four Station at Aman Perdana, Klang

\begin{tabular}{|c|c|c|c|c|c|c|c|c|c|c|c|c|c|}
\hline \multirow{3}{*}{ Element } & & \multirow{2}{*}{\multicolumn{3}{|c|}{ A }} & \multicolumn{6}{|c|}{ STATION } & \multirow{2}{*}{\multicolumn{3}{|c|}{ D }} \\
\hline & & & & & & B & & & C & & & & \\
\hline & & $\begin{array}{l}1 \\
\text { (ppm) }\end{array}$ & $\begin{array}{l}2 \\
\text { (ppm) }\end{array}$ & $\begin{array}{l}\text { Mean } \\
(\mathrm{ppm})\end{array}$ & $\begin{array}{l}1 \\
\text { (ppm) }\end{array}$ & 2 (ppm) & $\begin{array}{l}\text { Mean } \\
\text { (ppm) }\end{array}$ & $\begin{array}{l}1 \\
\text { (ppm) }\end{array}$ & 2 (ppm) & $\begin{array}{l}\text { Mean } \\
\text { (ppm) }\end{array}$ & $\begin{array}{l}1 \\
\text { (ppm) }\end{array}$ & 2 (ppm) & $\begin{array}{l}\text { Mean } \\
(\mathrm{ppm})\end{array}$ \\
\hline Aluminium & $(\mathrm{Al})$ & 8.026 & 8.125 & 8.0755 & 20.81 & 19.96 & 20.385 & 8.955 & 9.592 & 9.2735 & 9.441 & 2.726 & 6.083 \\
\hline Arsenic & (As) & Nil & Nil & Nil & 0.016 & 0.002 & 0.009 & Nil & Nil & Nil & Nil & Nil & Nil \\
\hline Calcium & (Ca) & 13.53 & 13.72 & 13.625 & 87.99 & 84.54 & 86.265 & 28.8 & 31.04 & 29.92 & 40.7 & 4.843 & 22.173 \\
\hline Cadmium & $(\mathrm{Cd})$ & Nil & Nil & Nil & Nil & Nil & Nil & Nil & Nil & Nil & Nil & $\mathrm{Nil}$ & Nil \\
\hline Chromium & $(\mathrm{Cr})$ & 0.03 & 0.029 & 0.0295 & 0.199 & 0.187 & 0.193 & 0.059 & 0.063 & 0.061 & 0.078 & 1.584 & 0.831 \\
\hline Iron & $(\mathrm{Fe})$ & 12.34 & 12.53 & 12.435 & 39.24 & 37.57 & 38.405 & 15.93 & 17.02 & 16.475 & 18.63 & 4.268 & 11.449 \\
\hline Potassium & $(\mathrm{K})$ & 3.085 & 3.112 & 3.0985 & 11.05 & 10.57 & 10.81 & 3.939 & 4.284 & 4.1115 & 4.522 & 1.013 & 2.767 \\
\hline Magnesium & $(\mathrm{Mg})$ & 2.193 & 2.22 & 2.2065 & 8.983 & 8.591 & 8.787 & 3.306 & 3.555 & 3.4305 & 4.157 & 0.743 & 2.45 \\
\hline Nickel & $(\mathrm{Ni})$ & 0.128 & 0.129 & 0.1285 & 0.148 & 0.141 & 0.1445 & 0.086 & 0.092 & 0.089 & 0.055 & 0.029 & 0.042 \\
\hline Lead & $(\mathrm{Pb})$ & 0.018 & 0.016 & 0.017 & 0.258 & 0.241 & 0.2495 & 0.057 & 0.06 & 0.0585 & 0.086 & 0.123 & 0.1045 \\
\hline Zinc & $(\mathrm{Zn})$ & 0.575 & 0.524 & 0.5495 & 7.198 & 7.062 & 7.13 & 2.191 & 2.303 & 2.247 & 3.3 & 0.268 & 1.784 \\
\hline
\end{tabular}




\section{ACKNOWLEDGMENT:}

The authors would like to thank to the Universiti Teknologi MARA (UiTM) especially the Faculty of Civil Engineering for giving a full support in order to ensure the success of this study.

\section{REFERENCES}

ATSDR. (2005). Toxicological Profile For Zinc. Case Study in Environmental Medicine for Agencies for Toxic Substances and Disease Registry, US Department of Health \& Human Services, Atlanta, Georgia.

ATSDR. (2008). Public Health Statement-Aluminium. Case Study in Environmental Medicine for Agencies for Toxic Substances and Disease Registry. US Department of Health \& Human Services, Atlanta, Georgia.

ATSDR. (2009). Arsenic Toxicity. Case Study in Environmental Medicine for Agencies for Toxic Substances and Disease Registry. US Department of Health \& Human Services, Atlanta, Georgia.

ATSDR. (2010). Lead Toxicity. Case Study in Environmental Medicine for Agencies for Toxic Substances and Disease Registry. US Department of Health \& Human Services, Atlanta, Georgia.

Byrd, T., Stack, M. And Furey, A. (2010). The Assessment Of The Presence And Main Constituents of Particulate Matter 10Microns (PM10) In Irish, Rural And Urban Air. Journal Of Atmospheric Environment, 44 (1) 75-87.

Colome, S.D., Kado, N.Y., Jaques, P. and Kleinman, M. (1992). Indoor-Outdoor Pollution Relations Particulate Matter Less Than 10 Micrometers In Aerodynamic Diameter PM10 In Homes Of Asthmatics. Journal Of Atmosphere Environment, 26 (12) 2173-2178.

DOS. (2011). Department of Statistic Malaysia. http://www.statistics.gov.my. Retrieved on August 2011.

EQA. (2011). Environment Quality Act (Malaysia). Environmental Quality (Clean Air) Regulations, 1978(Act 127). Regulation, Rules and orders. Environmental Quality Act 1974. Federal Subsidiary Legislation, Malaysia.

Lugo G, Cassady G, Palmisano P. (1969). Acute Maternal Arsenic Intoxication With Neonatal Death. American Journal of Diseases of Childeren, 117(3) 328-330.

MPK. (2011). Majlis Perbandaran Klang, Malaysia. http://www.mpklang.gov.my. Retrieved on august 2011.

Meyer, M.B and Rupprecht, E.G. (1996). Particulate Matter Sampling Methods: The Importance Of Standardization. Journal of Aerosol Science, 27, S349-S350.

Mulloli, T.P, King, A., Howel, D., Stone, I. And Merefield,J., (2000). PM10 Levels In Communities Close To And Away From Opencast Coal Mining Sites In Northeast England. Journal Of Atmospheric Environment, 34 (19) 30913101.

Peavy, H.S., Rowe, D.R. and Tchobanoglous, G., (1985). Environmental Engineering. International Edition. McGrawHill Book Co. Publication.

Talib, M.I, Rozali, M.o, Norela, S. Ahmad-Daud, M.N and Permata, N.J. (2002). Air Quality In Several Industrial Areas In Malaysia. Proceeding of the Regional Symposium on environmental and natural resources. $10-11$ April 2002, Kuala Lumpur, $703-710$.

Vallero, D.A, (2008). Fundamentals of Air Pollution. Academic Press, 273-275.

WHO. (2005). World Health Organization, WHO Air Quality Guidelines for Particulate Matter, Ozone, Nitrogen Dioxide and Sulphur Dioxide. Summary of Risk Assessment.. Global Update 2005. Geneva.

Yip,L and Dart, R.C.(2001). Arsenic: In Clinical Environmental Health and Toxicity Exposure. Lippincott Williams and Wilkins publication, 858. 